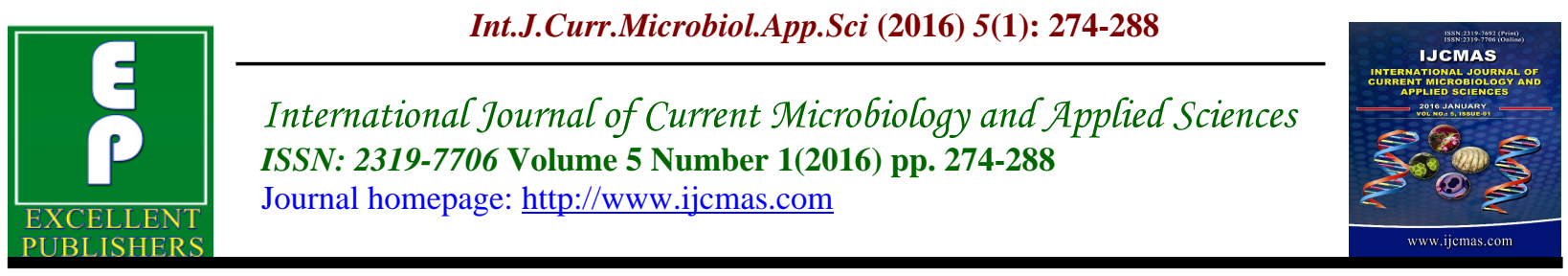

Original Research Article

hittp: //dx.doiorg/10.20546/ijcmas.2016.501.02

\title{
Investigation of $\mathrm{Cr}$ (VI) Uptake in Saline Condition Using Psychrophilic and Mesophilic Penicillium sp.
}

\author{
Manjari Barsainya, Prem Chandra and Devendra Pratap Singh* \\ Department of Environmental Science, Babasaheb Bhimrao Ambedkar (A Central) University, \\ Lucknow-226025, U.P., India \\ *Corresponding author
}

\begin{abstract}
A B S T R A C T
Keywords

Penicillium;

Biosorption;

$\mathrm{NaCl}$;

FTIR;

SEM

Article Info

Accepted:

22 December 2015

Available Online:

10 January 2016

Salt tolerant and chromium resistant fungal strains were isolated from two different sites i.e. psychrotolerant fungus PLF1, was isolated from Pangong lake of Laddakh, India and mesophilic strain PMS2, was isolated from garden soil. Present study was carried out on interaction of Penicillium sp. with chromium and $\mathrm{NaCl}$ and reports ability of Penicillium $s p$. to bind with chromium and $\mathrm{NaCl}$ in aqueous solution. Biosorption of the chromium ion $\mathrm{Cr}(\mathrm{VI})$ onto the cell surface of Penicillium fungal species in aerobic condition was also investigated. Results displayed 42.85 and $40.38 \%$ inhibition of mycelial growth in presence of $10 \% \mathrm{NaCl}$ and $100 \mathrm{ppm}$ concentration of $\mathrm{Cr}$ (VI), whereas 63.15 and $60.65 \%$ inhibition of mycelial growth was observed in absence of $\mathrm{NaCl}$ and $100 \mathrm{ppm}$ concentration of $\mathrm{Cr}$ (VI) in PLF1 and PMS2 fungal isolates respectively on $10^{\text {th }}$ day of incubation. It is demonstrated in the present study that $\mathrm{NaCl}$ reduced the extent of $\mathrm{Cr}$ biosorption and promote the fungal strains of Penicillium for better growth. FTIR spectrum was used to evaluate the membrane surface binding of chromium and $\mathrm{NaCl}$ by fungal strains of Penicillium.SEM was used to obtain the morphological as well as structural characterization of fungal pellets. The present finding suggests that $\mathrm{NaCl}$ might reduce the toxicity of hexavalent chromium in Penicillium sp. and may be used as a potential organism for remediation of chromium in high salinity environments.
\end{abstract}

\section{Introduction}

Chromium (Cr) toxicity is one of the major causes of environmental pollution which enter the agroecosystem from different sources like sewage sludge, tannery effluents and industrial operations such as smelting, mining etc. (Bai and Abraham, 2002). Of the various forms of chromium only hexavalent $\mathrm{Cr}(\mathrm{VI})$ and trivalent chromium $\mathrm{Cr}$ (III) have primary environmental significance because they are the most stable oxidation forms in the environment (Smith et al., 2002). The increasing concentrations of chromium in the soil affect adversely both the microbes and plants (Ahmad et al., 2005). High saline wastes are produced in different industrial 
activities, such as chemical manufacture, oil and gas production and waste minimization practices. This waste is composed of water containing high concentration of salts, oil, organic acids, heavy metals, and radionuclides (Woolard and Irvine, 1995) therefore, the potential of halotolerants to remediate pollutants such as heavy metals in the presence of salt is useful for biological treatment without damage to the physically sensitive ecosystem. Physico-chemical methods such as reverse osmosis, solvent extraction, lime coagulation ion exchange and chemical precipitation (Rich and Cherry, 1987) for removal of heavy metals from wastewater are agonize from extremely costs connected with energy and chemical consumption. Recently, microbes have been reported as the exploration for new and advanced technology for the remediation of heavy metal pollution (Kapoor and Viraraghvan 1995; Doelman et al., 1994). The present study attempts to isolate and identify heavy metal tolerant fungal strains from two different environments and to evaluate their chromium removal efficiency from liquid media in saline and non-saline conditions.

\section{Materials and Methods}

\section{Isolation of Chromium Tolerant Fungi}

Fungal strains were isolated from two different sites i.e. psychrotolerant fungus PLF1, was isolated from Pangong lake of Laddakh, India and mesophilic strain PMS2, was isolated from garden soil of BBAU Campus, Lucknow by serial dilution method using potato dextrose agar containing 100 ppm of $\mathrm{Cr}$ and $10 \%$ of $\mathrm{NaCl}$. The 1000 ppm stock solution $\mathrm{Cr}$ was made in double distilled water using $\mathrm{K}_{2} \mathrm{Cr}_{2} \mathrm{O}_{7}$. The stock solution of heavy metal was sterilized separately through bacteriological filters and added to sterilized potato dextrose agar
(PDA) medium to make the concentration at $50 \mathrm{ppm}$. Twenty milliliter of PDA medium (Hi Media, India) containing $50 \mathrm{ppm}$ of chromium and $10 \%$ of $\mathrm{NaCl}$ poured in these petri plates and incubated at $28^{\circ} \mathrm{C}$ for $72 \mathrm{~h}$. The colonies of predominant genera of fungi were picked up and purified by pour plate method. Isolates were tested for morphological, physiological and biochemical characters according to mycological literature. Fungal strains were purified and maintained on potato dextrose agar slants and plates at $4{ }^{\circ} \mathrm{C}$ for further use. Psychrotolerant PLF1 can grow at $20-40^{\circ} \mathrm{C}$, but also able to tolerate lower temperatures (up to $4^{\circ} \mathrm{C}$ ) with slower growth rates. However, low temperatures are not the only conditions that fungal strain PLF1 of glacial environments has to endure in order to survive.

\section{Screening of Fungal Isolates for Chromium Tolerance}

Chromium tolerant $(50 \mathrm{ppm})$ fungal isolates were further screened for tolerance to $\mathrm{Cr}$ at 100, 200 and 400 ppm of heavy metal on PDA in presence and absence of $10 \% \mathrm{NaCl}$. The discs of fungal isolates were kept on PDA medium containing 100, 200 and 400 ppm of chromium separately. Discs of fungal isolates on normal PDA medium served as control (normal growth) for comparison of growth of fungal isolates on PDA medium containing different concentration of heavy metal in presence and absence of $10 \% \mathrm{NaCl}$. Observations on growth of fungal isolate were made after 72 $h$ of incubation. The growth of fungal isolates was recorded as normal, moderate or absent in comparison to control. The isolated screened fungal isolates were identified on the basis of cultural and morphological characters (Gilman, 1957; Barnett and Hunter, 1972). 
Uptake of Chromium by Fungal Isolates from Liquid Media

The highly tolerant fungal isolates to heavy metal were evaluated for uptake of chromium in potato dextrose broth medium containing 20,40,60, 80 and $100 \mathrm{ppm}$ concentration of $\mathrm{Cr}$ in presence and absence of $10 \% \mathrm{NaCl}$. Potato dextrose broth with and without $10 \% \mathrm{NaCl}$ and containing $20,40,60,80$ and $100 \mathrm{ppm}$ of $\mathrm{Cr}$ was dispensed in $100 \mathrm{ml}$ lots to $250 \mathrm{ml}$ conical flasks and sterilized at $15 \mathrm{lbs} / \mathrm{psi}$ for $15 \mathrm{~min}$. These flasks were inoculated with $1 \mathrm{ml}$ of freshly prepared spore suspension $\left(10^{6}-10^{7}\right.$ spores $/ \mathrm{ml}$ ) of each fungal isolate and kept in static condition at $28^{\circ} \mathrm{C}$ for $96 \mathrm{~h}$. Uninoculated flasks containing PD broth of 20,40, 60, 80 and $100 \mathrm{ppm}$ concentration of $\mathrm{Cr}$ in the presence and absence of $\mathrm{NaCl}$, served as control. Fungal growth was harvested after $96 \mathrm{~h}$ through filtration using Whatman filter No. 42. The harvested fungal biomass was rinsed with double distilled water 3-4 times and dried in hot air oven at $80^{\circ} \mathrm{C}$ for $18 \mathrm{~h}$. The dried fungal biomass was weighed and heavy metal concentration in it was estimated by digestion with nitric acid and perchloric acid (3:1 ratio). The digested fungal biomass was filtered through Whatman filter No. 42 and made the volume of filtrate to $50 \mathrm{ml}$ in volumetric flask.

The heavy metals concentration in filtrate was estimated (Greenberg et al., 1985) by Atomic Absorption Spectrophotometer (AA 240 FS: Fast Sequential AAS Varian, Netherland) All the experiments were conducted in triplicate and data were analyzed statistically. Growth and uptake of $\mathrm{Cr}$ by both mesophilic (PMS2) and psychrophilic (PLF1) fungi in presence and absence of $10 \% \mathrm{NaCl}$ in PD broth was studied. The uptake of chromium by fungal biomass was calculated using the following equation: qe $(\mathrm{mg} / \mathrm{g})=\frac{\mathrm{C} \times \mathrm{V} \times 1000}{\mathrm{~W}}$

qe concentration of chromium cumulated by fungal biomass, $(\mathrm{mg} / \mathrm{g})$; $\mathrm{C}$ concentration of chromium (ppm); V (ml) the volume of the liquid medium and $\mathrm{W}(\mathrm{g})$ is the dry weight of the fungal biomass.

\section{Microscopic Characterization}

\section{Scanning Electron Microscopic Observations}

The fungal mycelia harvested during the mid-exponential phase and taken in to eppendorf tube and were fixed with $2.5 \%$ of glutaraldehyde (Loba Chemi, INDIA) solution in Milli-Q (M.Q) water for 1- 2 hours at room temperature. Fixed culture were washed twice with M.Q water, and post-fixed with $0.5 \mathrm{ml}$ of $2 \%$ Osmium tetra oxide for 1 hour. The culture was subsequently dehydrated using a series of 10, 30, 50, 70, 90 and 100\% ethanol in M.Q water for 5 minutes. The final dehydration in $100 \%$ of ethanol was carried out for 10 minutes. The dehydrated culture drop was fixed on the cover slip and then dried overnight in an oven and desiccator till mounting.

The specimen was mounted over stainless steel stab with double-stick carbon adhesive tapes and coated with platinum using a sputter coater prior to viewing using a scanning electron microscope of JEOL (JSM 6490 LV) JAPAN. (Fig 6 and Fig:7).

\section{Fourier Transform Infrared Spectra (FTIR) Analysis}

The cell surface binding characteristics of PMS2 and PLF1biomass before and after adsorption of $\mathrm{Cr}$ (VI) with and without $\mathrm{NaCl}$ were analyzed by using Fourier Transform 
Infra-Red Spectrometer (FTIR) of ThermoScientific (Nicole 6700). The midexponential phase growing fungal biomass was harvested by using Whatman No 1 filter paper. Biomass of both the strains treated with $60 \mathrm{ppm}$ of $\mathrm{Cr}$ (VI) with and without $\mathrm{NaCl}$ was analyzed. The fungal biomass without treatment of chromium and $\mathrm{NaCl}$ was treated as control. Biomass was washed three times with M.Q water and then dried in hot air oven at $60^{\circ} \mathrm{C}$ for 24 hour. The dried fungal biomass samples and Potassium bromide $(\mathrm{KBr})$ (1/100 ratio) were grinded pressed to form pellet by using a manual hydraulic press $(150 \mathrm{lb})$.The IR spectra (4000-400 $\left.\mathrm{cm}^{-1}\right)$ were obtained with resolution of $5-7 \mathrm{~cm}^{-1}$ with the 32 scan number for each spectrum, using (FTIR) (Thermo- Scientific Nicole 6700, USA).

\section{Results and Discussion}

\section{Isolation of Chromium Tolerant Fungi}

Five fungal isolates tolerant to Chromium $(50 \mathrm{ppm})$ were isolated from garden soil of BBAU Campus, Lucknow and only one chromium tolerant fungal strain was isolated from Pangong lake of Laddakh, India using standard methods (Gilman, 1957). Isolate PLF1 and PMS2 were selected from the collection of all strains as they displayed maximum salinity tolerance capacity and high chromium tolerance. Isolate PLF1 and PMS2 were identified according to the mycological literature and assumed to be a member of the genus Penicillium. Based on slide preparation, biochemical and physiological characteristics isolate PLF1 and PMS2 was reaffirmed and identified as Penicillium.

\section{Screening of Fungal Isolates for Salt and Chromium Tolerance}

All fungal isolates were further screened for their tolerance to at 50,100, 200 and 400 $\mathrm{ppm}$ of Cr. Data indicated decrease in number of isolates tolerant to $\mathrm{Cr}$ at higher concentration of metal. Among all fungal isolates tolerant to $\mathrm{Cr}$ at $50 \mathrm{ppm}$, only two isolates could tolerate $\mathrm{Cr}$ at $400 \mathrm{ppm}$. Similar trend was observed for screening of fungal isolates for their tolerance to salinity. Inhibition of some of the fungal isolates at higher concentration of Chromium is observed. Similar observations about toxic effect of higher concentration of heavy metals on growth of fungi have been reported. (Malik A 2004 and Rama Rao et al., 1997)

\section{Uptake of Chromium by Fungal Isolates from Liquid Media}

The maximum dry weight $(0.61 \mathrm{~g})$ was observed in mesophilic strain of Penicillium-PMS2, followed by psychrophilic strain of Penicillium-PLF1 $(0.57 \mathrm{~g})$ in potato dextrose broth containing $60 \mathrm{ppm}$ of $\mathrm{Cr}$. The maximum uptake $(0.062$ $\mathrm{mg} / \mathrm{g}$ ) of $\mathrm{Cr}$ was observed in PMS2. Minimum uptake $\mathrm{Cr}(0.032 \mathrm{mg} / \mathrm{g})$ found in PLF1 in PD broth containing $60 \mathrm{ppm}$ of $\mathrm{Cr}$ respectively (Table 3). The highest uptake of $\mathrm{Cr}(0.062 \mathrm{mg} / \mathrm{g})$ by PMS2 indicated its efficiency to remove $\mathrm{Cr}$ from aqueous solution in non-saline medium containing higher concentration of $\mathrm{Cr}(60 \mathrm{ppm})$. These results with respect to uptake of $\mathrm{Cr}$ by fungi are in agreement with those reported earlier (Gopal et al., 2002; Preetha andViruthagiri 2007; Congeeraram et al., 2007).

\section{Effect of Chromium and Salt Concentration on Mycelial Growth}

Isolates PLF1 and PMS2 could tolerate salinity level upto $0-15 \%$. Salt shock upto $5 \% \mathrm{NaCl}$ did not affect the growth, but higher osmotic stress of above $10 \%$ brought significant reduction in fungal biomass by 
$27.63 \%$ and $33.07 \%$ in PLF1 and PMS2 respectively, in comparison to non-saline conditions (Fig 1). Results also displayed 63.15 and $60.65 \%$ inhibition of mycelial growth in absence of $\mathrm{NaCl}$ and 100 ppm concentration of $\mathrm{Cr}$ (VI), in PLF1 and PMS2 respectively on $10^{\text {th }}$ day of incubation (Fig 2 ), whereas 42.85 and $40.38 \%$ inhibition of mycelial growth was observed in presence of $10 \% \mathrm{NaCl}$ and $100 \mathrm{ppm}$ concentration of $\mathrm{Cr}$ (VI), in PLF1 and PMS2 respectively on $10^{\text {th }}$ day of incubation (Fig3).

Growth and Uptake of Chromium in Saline and Non-saline Medium

The maximum dry weight $(0.40 \mathrm{~g})$ was observed in mesophilic fungi PMS2 followed by psychrotolerant strain of Penicillium PLF1 (0.38 g) in presence of $10 \% \mathrm{NaCl}$. There was 0.032 and $0.041 \mathrm{mgg}^{-}$

${ }^{1}$ reduction of chromium was observed by psychrotolerant fungi PLF1 and 0.046 and $0.062 \mathrm{mg} \mathrm{g}^{-1}$ reduction of chromium was observed by mesophilic fungi PMS2 in presence of saline and non-saline medium respectively, invitro conditions. (Table: 1) These results with respect to uptake of $\mathrm{Cr}$ by fungi are in agreement with those reported earlier (Congeeraram et al., 2007).

\section{Fourier Transform Infrared Spectroscopy (FTIR)}

The possible metal binding sites were identified by FTIR spectral analysis (wave numbers $400-4000 \mathrm{~cm}^{-1}$ ) by comparing control and treated biomass of fungal strains (Fig 4 and Fig 5). Clear spectral changes were observed after biosorption of chromium on fungal biomass as shown in Table 2 and 3. The results showed that the cell surface of fungal strains contain several functional groups such as carbohydrate, amide, amine and hydroxyl groups which contribute to chromium binding by the cell surface of both Penicillium strains. The functional groups such as carboxyl, hydroxyl, amide, phosphate and sulphonate groups have been recognized as potential adsorption sites to be accountable for binding metallic ions to fungi (Das and Guha 2007).

Their potential for metal uptake depends on factors such as the abundance of sites, their accessibility, chemical state and affinity between adsorption site and metal. (Subbaiah et al., 2008).The FTIR spectra of Penicillium after treatment of chromium and chromium with $\mathrm{NaCl}$ displayed changes in spectral peaks (Table 2 and Table 3). Shifting of the FTIR peak in the range of $3500-3300 \mathrm{~cm}^{-1}$ were indicating the presence of hydroxyl group (O-H stretch) and secondary amide (N-H stretch) which after adsorption of chromium shifted to 3384.9 and 3356.9 in PLF1 and PMS2 respectively. After adsorption of chromium the wave numbers $2358.5 \mathrm{~cm}^{-1}$ shifted to 2361.1 showed asymmetric $\mathrm{CO}_{2}$ stretching (Schultz et al.,1996) in mesophilic Penicillium PMS2.

Peaks at $1740.2 \mathrm{~cm}^{-1}$ can be attributed to ( $\mathrm{C}=\mathrm{O}$ stretching) band of carboxylic or ester groups shifted to 1743.1.The wave numbers 1647.4, 1538.5and 1647.3, 1550.4 shifted due to the stretching in $\mathrm{C}=\mathrm{O}$ of amide-I and $\mathrm{N}-\mathrm{H}$ of amide-II band of proteins (Chandra et al., 2014) after chromium adsorption in PMS2 and PLF1 strains respectively. A new peak emerged in the range of $1455.1 \mathrm{~cm}^{-1}$ in PMS2 strain is closely related to $\mathrm{N}-\mathrm{H}$ bending and $\mathrm{C}-\mathrm{N}$ stretching frequencies. Fourier transform infrared (FTIR) analysis was carried out to determine the involvement of the type of functional groups in metal adsorption. Fein et al. reported that some components of the cell wall serve as electron donors for the reduction reaction while metal binding. 
Table.1 Growth and Uptake of Cr by Fungi from Liquid Medium Containing 60 ppm Chromium

\begin{tabular}{|c|c|c|c|c|}
\hline PLF1 & & PMS2 & & \\
\hline $\mathrm{Cr} 60 \mathrm{ppm}$ & $10 \% \mathrm{NaCl}$ & $\mathrm{No} \mathrm{NaCl}$ & $10 \% \mathrm{NaCl}$ & $\mathrm{No} \mathrm{NaCl}$ \\
\hline Dry weight $(\mathrm{g})$ & 0.38 & 0.30 & 0.40 & 0.34 \\
\hline Cr Uptake $(\mathrm{mg} / \mathrm{g})$ & .032 & .041 & .046 & .062 \\
\hline
\end{tabular}

Table.2 Assignment of Functional Groups Associated with Major Vibration Bands in Mid-IR Spectra of Psychrophilic Penicillium (PLF1)

\begin{tabular}{|c|c|c|c|c|}
\hline $\begin{array}{l}\text { Representing } \\
\text { range of } \\
\text { wavenumber in } \\
\text { cm }^{-1}\end{array}$ & $\begin{array}{l}\text { PLF1 } \\
\text { Control }\end{array}$ & $\begin{array}{l}\text { PLF1 with Cr } \\
60 \mathrm{ppm}\end{array}$ & $\begin{array}{l}\text { PLF1 with } 10 \% \\
\text { NaCl and } \mathrm{Cr} 60 \\
\text { ppm }\end{array}$ & Band assignment \\
\hline $3500-3300$ & 3391.1 & 3384.9 & 3389.1 & $\begin{array}{l}\mathrm{O}-\mathrm{H} \text { (asym.) and N-H stretching of } \\
\text { secondary amides (Coates, 2000; Yang } \\
\text { et al., 2005; Paluszkiewicz and Kwiatek, 2001) }\end{array}$ \\
\hline $2950-2700$ & & 2927.1 & 2930.7 & C-H stretching (Bellamy, 1954) \\
\hline $1660-1600$ & 1647.3 & 1651.4 & 1647.6 & $\begin{array}{l}\text { Amide-I band arises from C=O stretching } \\
\text { vibrations (Paluszkiewicz and Kwiatek, 2001) }\end{array}$ \\
\hline $1550-1510$ & 1550.4 & 1550.0 & 1538.7 & $\begin{array}{l}\text { Amide-II band (arises from C-N \& C-H bending } \\
\text { vibrations (Sethuraman and Balasubramanian, } \\
\text { 2010; Eckel } \text { et al., 2001) }\end{array}$ \\
\hline 1377 & 1377.8 & 1376.6 & 1378.7 & $\begin{array}{l}\mathrm{C}-\mathrm{H} \text { bending modes of } \mathrm{CH}_{2} \\
\text { (Erukhimovitch } \text { et al., 2005) }\end{array}$ \\
\hline $1270-1230$ & 1235.3 & 1236.9 & 1230.5 & $\begin{array}{l}\mathrm{PO}^{2-} \text { stretching vibrations and phospholipids } \\
\text { (Erukhimovitch } \text { et al., 2005) }\end{array}$ \\
\hline \multirow[t]{2}{*}{$1090-990$} & & 1076.7 & & $\begin{array}{l}\text { Carbohydrate and nucleic acid vibrations } \\
\text { (Salman } \text { et al., 2012) }\end{array}$ \\
\hline & 1037.0 & 1038.2 & 1076.6 & $\begin{array}{l}\mathrm{P}=\mathrm{O} \text { stretching } \\
(\text { Das and Guha 2007) }\end{array}$ \\
\hline $630-530$ & 562.4 & 570.1 & 571.8 & $\begin{array}{l}\text { Nitro compounds and disulfide groups } \\
\text { (Ramrakhiani et al., 2011) }\end{array}$ \\
\hline
\end{tabular}


Table.3 Assignment of Functional Groups Associated with Major Vibration Bands in Mid-IR Spectra of Mesophilic Penicillium (PMS2)

\begin{tabular}{|c|c|c|c|c|}
\hline \multicolumn{5}{|c|}{ Observed wavenumber $\left(\mathrm{cm}^{-1}\right)$ at different concentration of $\mathrm{Cr}(\mathrm{VI})$} \\
\hline $\begin{array}{l}\text { Representing } \\
\text { range of } \\
\text { frequency in } \\
\mathrm{cm}^{-1}\end{array}$ & $\begin{array}{l}\text { PMS2 } \\
\text { Control }\end{array}$ & $\begin{array}{ll}\text { PMS2 } & \\
\text { with } & 60 \\
\text { ppm } & \text { Cr } \\
\text { (VI) } & \\
\end{array}$ & $\begin{array}{l}\text { PMS2 with } \\
10 \% \mathrm{NaCl} \text { and } \\
60 \mathrm{ppm} \mathrm{Cr} \text { (VI) }\end{array}$ & Band assignment \\
\hline $3400-3300$ & 3391.3 & 3356.9 & 3396.7 & $\begin{array}{l}\mathrm{O}-\mathrm{H} \text { and } \mathrm{N}-\mathrm{H} \text { stretching of sec-amides } \\
\text { (Coates, 2000; Yang et al., 2005; Paluszkiewicz and } \\
\text { Kwiatek, 2001) }\end{array}$ \\
\hline $3050-2850$ & 2926.9 & 2926.6 & 2927.4 & $\begin{array}{l}\mathrm{CH}_{2} \text { asymmetric stretching } \\
(\text { Naumann 2011) }\end{array}$ \\
\hline $2862-2843$ & 2856.7 & 2857.1 & 2857.5 & (C-H) stretching (Bellamy, 1954). \\
\hline $2400-2300$ & 2358.5 & 2361.1 & & $\begin{array}{l}\text { Asymmetric CO2 stretching (Jackson } \\
\text { et al., 1998) }\end{array}$ \\
\hline $1760-1720$ & 1740.2 & & 1743.1 & $\begin{array}{l}\mathrm{C}=\mathrm{O} \text { stretching of ester } \\
\text { (Dukor 2001;Chandra et al., 2014) }\end{array}$ \\
\hline $1700-1600$ & 1647.4 & 1649.9 & 1648.2 & $\begin{array}{l}\text { Amide-I band proteins arises from } \mathrm{C}=\mathrm{O} \text { stretching } \\
\text { (Paluszkiewicz and Kwiatek, 2001); }\end{array}$ \\
\hline $1560-1530$ & 1538.5 & 1542.6 & 1552.3 & $\begin{array}{l}\text { Amide II }(\mathrm{N}-\mathrm{H}), \mathrm{C}-\mathrm{N} \text { stretching (Sethuraman } \\
\text { and Balasubramanian, 2010) }\end{array}$ \\
\hline $1450-1400$ & & 1455.1 & & $\begin{array}{l}\text { C-N stretching and N-H bending of Amide- III band } \\
\text { of protein (Eckel et al., 2001)) }\end{array}$ \\
\hline $1400-1360$ & 1377.8 & 1377.2 & 1376.1 & $\begin{array}{l}\mathrm{CH} \text { bending mode of } \mathrm{CH}_{2} \\
\text { ( Erukhimovitch et al., 2005) }\end{array}$ \\
\hline \multirow[t]{2}{*}{$1270-1230$} & 1234.8 & 1239.5 & 1237.1 & $\begin{array}{l}\mathrm{PO}^{2-} \text { stretching vibrations and phospholipids } \\
\text { (Yang } \text { et al., 2005) }\end{array}$ \\
\hline & & 1152.5 & 1151.9 & $\begin{array}{l}\mathrm{CO}-\mathrm{O}-\mathrm{C} \text { stretch in polysaccharides (Maquelin } \\
\text { et al., 2002) }\end{array}$ \\
\hline \multirow[t]{2}{*}{$1100-1050$} & 1076.7 & 1077.0 & 1077.6 & $\begin{array}{l}\text { Carbohydrate and nucleic acid vibrations } \\
\text { (Salman et al., 2012) }\end{array}$ \\
\hline & 1041.9 & 1040.3 & 1039.3 & $\begin{array}{l}\mathrm{P}=\mathrm{O} \text { stretching } \\
(\text { Das and Guha 2007) }\end{array}$ \\
\hline $630-530$ & 572.9 & 577.5 & 569.4 & $\begin{array}{l}\text { Nitro compounds and disulfide groups } \\
\text { (Ramrakhiani et al., 2011) }\end{array}$ \\
\hline
\end{tabular}


Figure.1 Growth of Fungal Strains with Different Conc. of $\mathrm{NaCl}(0-15 \%)$

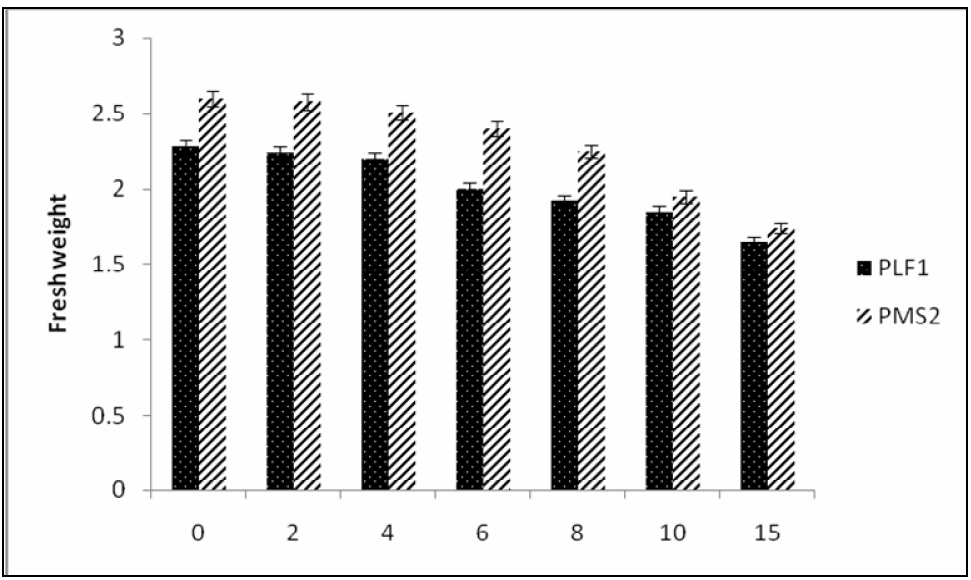

Figure.2 Growth of fungal Strains with Different Concentrations of $\mathrm{Cr}$ (VI) in Absence of $\mathrm{NaCl}$

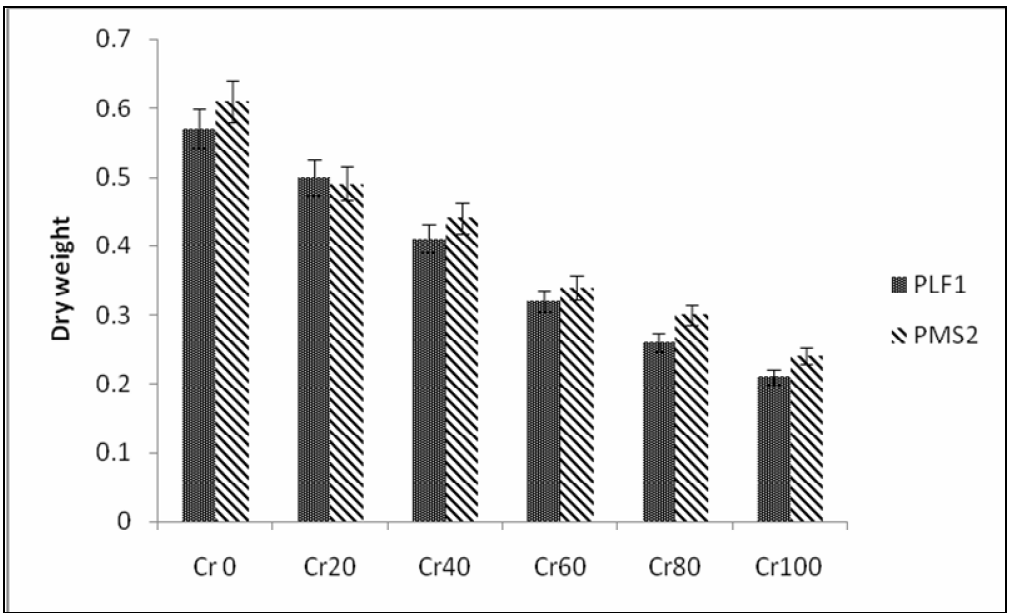

Figure.3 Growth of Fungal Strains with Different Chromium Concentrations and 10\% $\mathrm{NaCl}$

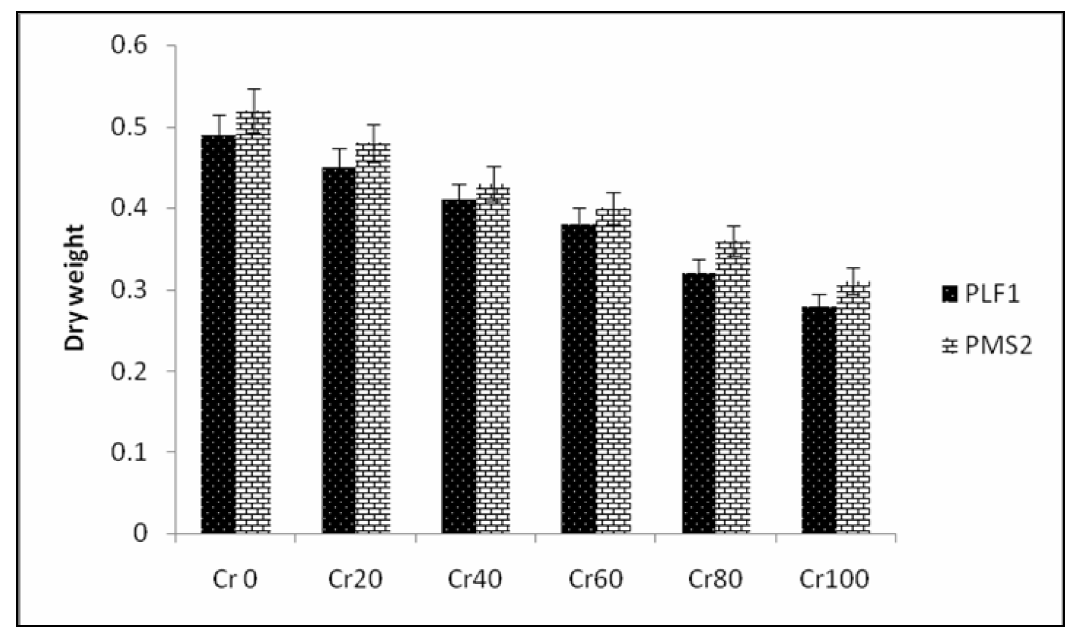


Fig.4 A- (Laddakh Penicillium) PLF1 Control, B- PLF1 with 10\% NaCl and Cr 60ppm, C- PLF1 with $\mathrm{Cr}$ 60ppm

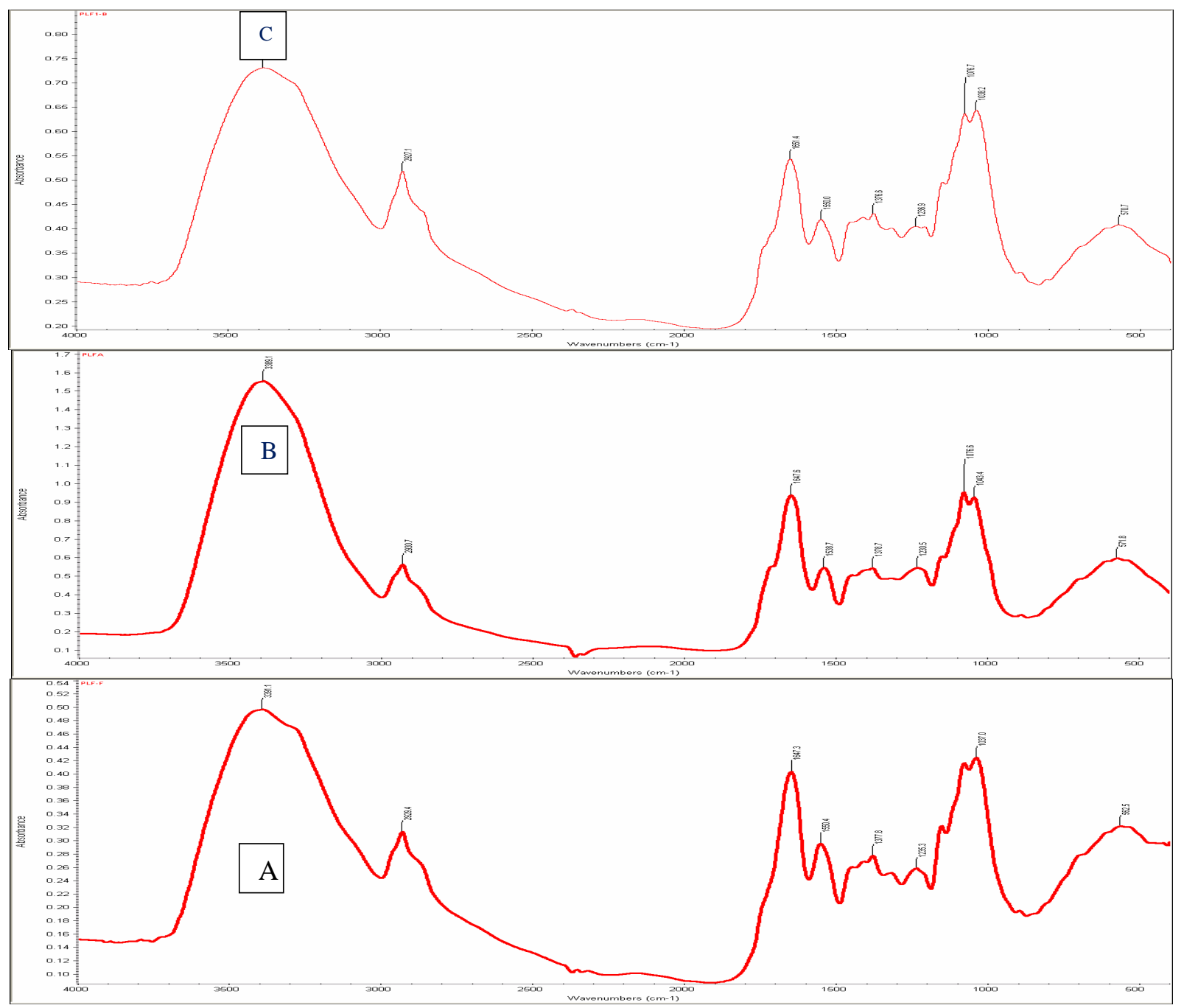


Fig.5 A- (Field soil Penicillium) PMS2 Control B- PMS2 with $\mathrm{NaCl} 10 \mathrm{ppm}$ and Cr 60ppm, CPMS2 with Cr 60 ppm

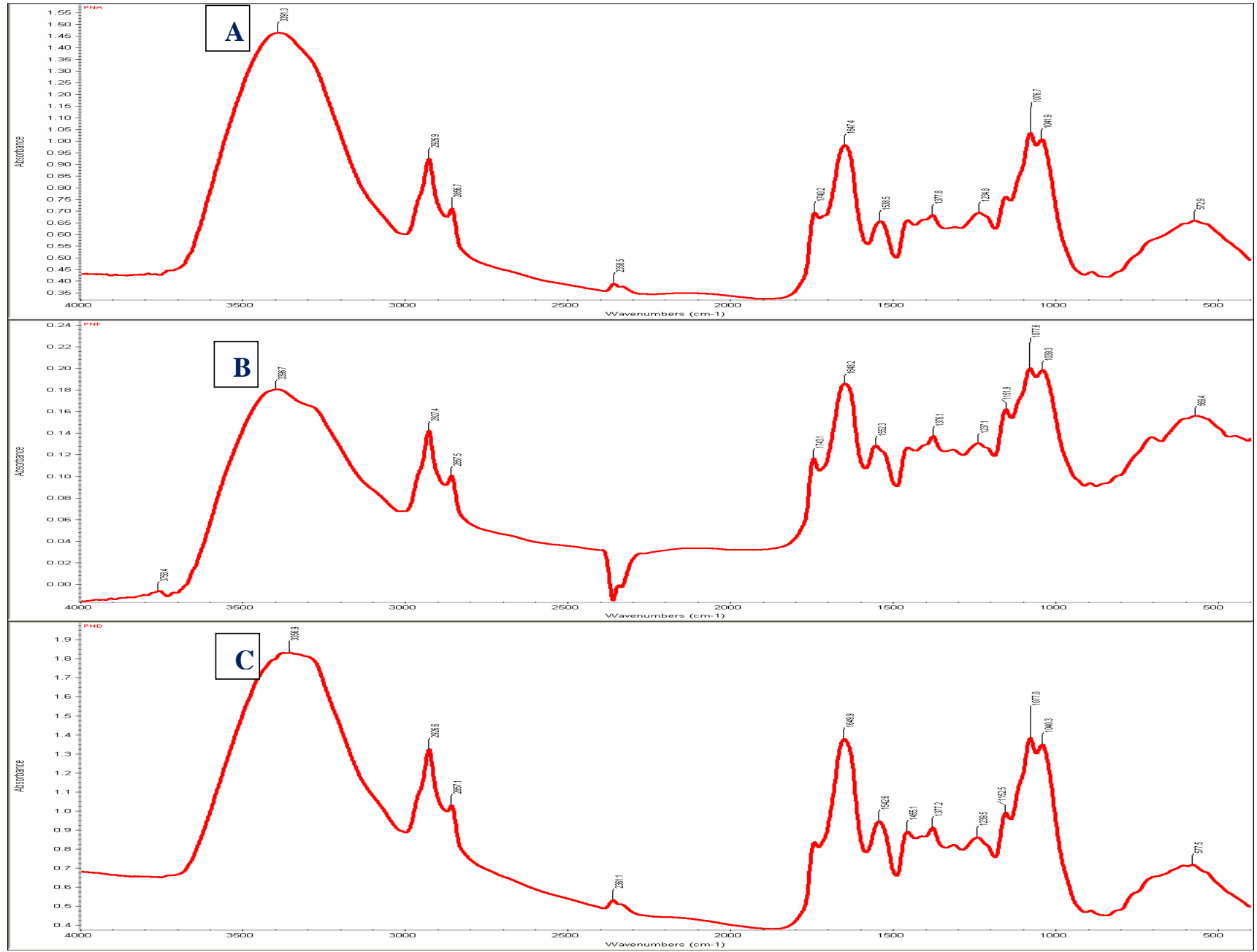

Fig.6 Scanning Electron Micrograph of Mesophilic Penicillium PMS2

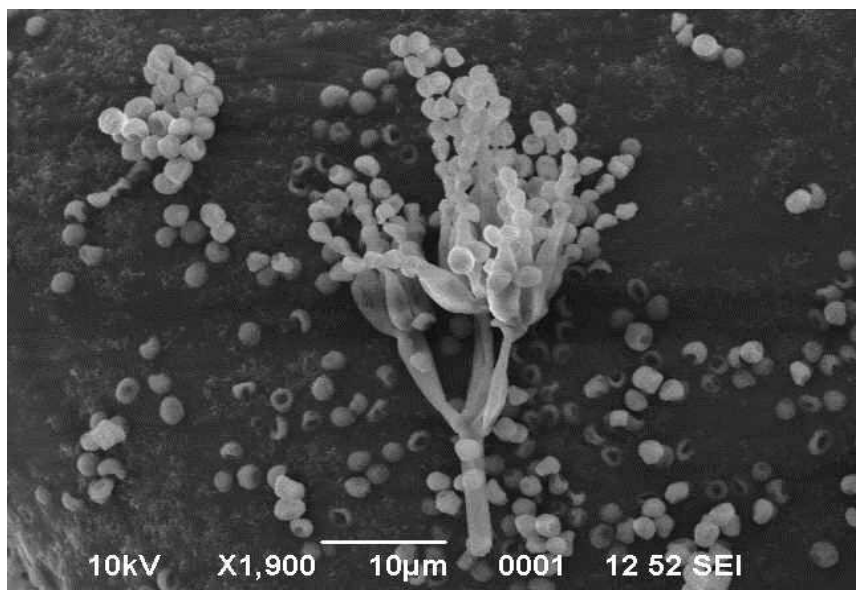


Fig.7 Scanning Electron Micrograph of Psychrophilic Penicillium PLF1

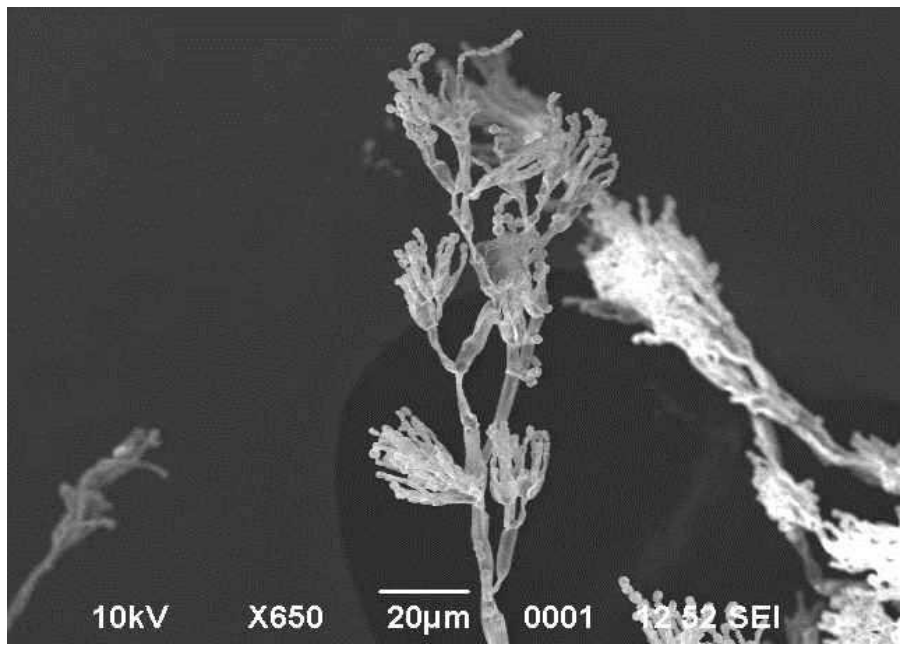

Biosorption of metals by microbial biomass is mainly based upon physicochemical interactions between metals and functional groups of the cell wall (Wu et al., 2010).

To the best of our knowledge this is the first report on psychrotolerant Pangong Lake fungus PLF1 for the removal of Cr (VI) with comparison to other mesophilic soil fungi PMS2 in saline and non-saline conditions. Chromium contamination of the environment has become an important issue due to the potential health threat it poses. Conventional technologies to clean up heavy metal ions from contaminated waters have been utilized, but they remain costineffective. Therefore, the use of such fungal biomass for the detoxification of $\mathrm{Cr}$ (VI) from metal contaminated sites may be a novel and cost-effective alternative. Data revealed that Penicillium $s p$. removed substantial amount of Chromium $(.032 \mathrm{mg} / \mathrm{g}$ by PLF1) and (.046 mg/g by PMS2) in presence of $10 \% \mathrm{NaCl}$. This indicated the potential biosorption capacity of Penicillium to remove chromium metal in saline condition. The FTIR observation demonstrates the involvement of amino, carboxylic, phosphate, sulfonyl and carbonyl functional groups in $\mathrm{Cr}$ (VI) biosorption. It is concluded from this study that $\mathrm{NaCl}$ improved the chromium tolerance and bioaccumulation properties in Penicillium sp. and could be used as a potential organism for chromium remediation in high salinity environments.

\section{Acknowledgment}

We acknowledge the laboratory facilities provided by the Head, Department of Environmental Science and also grateful to the Director, USIC, B. B. Ambedkar University, Lucknow, for providing SEM and FTIR facility. Manjari Barsainya is thankful to the University Grants Commission (UGC), New Delhi, for providing financial support in the form of research fellowship.

\section{References}

Ahmad, I., Zafar S. and Ahmed, F., 2005. Heavy Metal Biosorption potential of Aspergillus and Rhizopus sp. isolated from Wastewater treated soil J. Appl. Sci. Environ. Man., 9(1): 123-126 
Bai R. S. and Abraham T. E., 2002. Studies on enhancement of $\mathrm{Cr}(\mathrm{VI})$ biosorption by chemically modified biomass of Rhizopus nigricans," Water Research, vol. 36, no. 5, pp. 1224-1236.

Barnett, H.L. and B.B. Hunter, 1972. Illustrated Genera of Imperfect Fungi. 2nd Edn., Minneapolis Burgress Publishing Co., Minneapolis, Pages: 241.

Bellamy,L.J.,1954.The Infra-Red Spectra of Complex Molecules. JohnWiley \& Sons, NewYork.

Chandra. P., Barsainya, M. and Singh, D.P., 2014. A Fourier Transform Infrared (FTIR) spectroscopic study on cellular changes in the Marinococcus luteus sslb 1 under different salinity regime. International Journal of Pharma and Bio Sciences, 5 (4): (B) 848 - 854.

Coates, J., 2000. Interpretation of infrared spectra, A Practical Approach. Meyers, R. A.(Ed.), Encyclopaedia Anal. Chem. 10815-10837.

Congeeraram S, Dhanarani S, Park J, Dexilin M, Thamaraiselvi K (2007) Biosorption of chromium and nickel by heavy metal resistant fungal and bacterial isolates. J Hazard Mater 146:270-277

Das, S.K., Guha, A.K., (2007). Biosorption of chromium by Termitomyces clypeatus. Colloids and Surfaces B: Biointerfaces, 60:46-54.

Doelman, P.; Jansen, E.; Michels, M.; van Til, M. 1994. Effects of heavy metals in soil on microbial diversity and activity as shown by the sensitivity-resistance index, an ecologically relevant parameter. Biol. Fertil. Soils, 17, 177-1784.

Eckel,R.,Huo,H.,Guan,H.W.,Hu,X.,Che,X., Huang, W.D. 2001. Characteristic infrared spectroscopic patterns in the protein bands of human breast cancer tissue. Vib. Spectrosc. 27,165-173.

Erukhimovitch, V., Pavlov, V. Talyshinsky, M., Souprun, Y., Huleihel. M. (2005) . FTIR microscopy as a method for identification of bacterial and fungal infections Journal of Pharmaceutical and Biomedical Analysis, 37 1105-1108

Fein, J. B., Fowle, D. A., Cahill, J., Kemner, K., Boyanov, M. and Bunker, B., 2002. Nonmetabolic reduction of chromium (VI) by bacterial surface under nutrient absent conditions. Geomicrobiol. J., , 19, 369-382

Gilman, J.D., 1957. A Manual of Soil Fungi. Iowa State University Press, Ames, Iowa, USA., Pages: 450.

Gopal M, Pakshirajan K, Swaminathan T (2002) Heavy metal removal by biosorption using Phanerochaete chrysosporium. Appl. Biochem. Biotechnol 102:227-237

Greenberg AE, Trussell RR, ClesceriLS., 1985. Standard methods for the examination of water and wastewater. 16. Washington, DC: American Public Health Association;. pp. 146-150.

Jackson, M., Ramjiawan, B., Hewko, M., Mantsch, H.H., 1998. Infrared microscopic functional group mapping and spectral clustering analysis of hypercholosterolomic rabbitliver. Cell Mol. Biol. 44,89-98.

Kapoor, A.; Viraraghvan, T. 1995, Fungal biosorption-An alternative treatment option for heavy metal bearing wastewater: A review. Bioresour. Technol. 53, 195-206.

Malik A., (2004). Metal bioremediation through growing cells. J Environ Int 30:271-278

Maquelin, K., Smith, L.P.C., Kirschner, C., Ngo-Thi, N.A., Naumann, D., Puppels, G.J., 2001. Handbook of Vibrational Spectroscopy, Wiley, Chichester, UK, pp. 3308-3334.

Naumann. D., 2011. FTIR and FT-Raman Spectroscopy in biomedical research. Applied Spectroscopy Reviews. 36 (2-3): 239-298. 
Paluszkiewicz, C., Kwiatek, W.M., 2001. Analysis of human cancer prostate tissues using FTIR microscopy and SXIXE techniques. J.Mol.Struct.565-566329334.

Preetha B, Viruthagiri T (2007) Batch and continuous biosorption of chromium (VI) by Rhizopus arrhizus. Sep Purif Technol 57:126-133

R.K. Dukor, 2001. Handbook of Vibrational Spectroscopy, Wiley, Chichester, UK, pp. 3335-3360.

Rama Rao VSKV, Akhtar N, Maruthi MP (1997) Isolation of a cadmium tolerant Curvularia sp. for polluted effluent. CurrSci 73:453

Ramrakhiani, L., Majumder, R., Khowala. S., (2011). Removal of hexavalent chromium by heat inactivated fungal biomass of Termitomyces clypeatus: Surface characterization and mechanism of biosorption. Chemical Engineering Journal $171: 1060$ - 1068

Rich G., Cherry K., (1987) Hazardous Waste Treatment Technologies, Pudvan Publishers, New york.

Salman, A Lapidot, I., Pomerantz, A., Tsror, L., Hammody, Z., Moreh,R., Huleihel, M., and Mordechai, S. (2012). Detection of Fusarium oxysporumFungal Isolates Using ATR Spectroscopy. Hindawi Publishing Corporation Spectroscopy: An International Journal Volume 27, Issue 5-6, Pages 551-556.

Schultz. C.P., Eysel. H.H., Mantsch, H.H. and Jackson. M.,1996. Carbon Dioxide in
Tissues, Cells, and Biological Fluids Detected by FTIR Spectroscopy. The Journal of Physical Chemistry., 100, 6845-6848.

Sethuraman,P., Balasubramanian, N. 2010. Removal of $\mathrm{Cr}$ (VI) from aqueous solution using Bacillus subtilis, Pseudomonas aeruginosa and Enterobacter cloacae. Int. J. Eng. Sci. Technol. 2,1811-1825.

Smith W. A., Apel W. A., Petersen J. N., and Peyton B. M., 2002. Effect of carbon and energy source on bacterial chromate reduction. Bioremediation Journal, vol. 6 , pp. 205-215.

Subbaiah, M.V., Kalyani, S., Reddy, G. S., Boddu.V. M., and Krishnaiah A., 2008. Biosorption of $\mathrm{Cr}$ (VI) from Aqueous Solutions Using Trametes Versicolor polyporus Fungi E-Journal of Chemistry. 5 (3) 499-510.

Woolard, C.R. and Irvine R.L., 1995. Treatment of hypersaline wastewater in the sequencing batch reactor. Water Res., 29: 1159-1168

Wu Y, Zhang L, Gao C, Ma X, Han R (2010). Adsorption of copper ions and methylene Blue in a single and Binary System on Wheat straw. J. Chem. Eng. Data, 54: 3229-3234.

Yang,Y., Sule-Suso,J., Sockalingum, G.D., Kegelaer, G., Manfait, M., ElHaj, A.J., 2005. Study of tumor cell invasion by Fourier transform infrared microspectroscopy. Biopolymers 78, $311-317$.

\section{How to cite this article:}

Manjari Barsainya, Prem Chandra and Devendra Pratap Singh. 2016. Investigation of Cr (VI) Uptake in Saline Condition Using Psychrophilic and Mesophilic Penicillium sp. Int.J.Curr.Microbiol.App.Sci. 5(1): 274-288. ihttp:///dx.doi.org/10.20546/ijcmas.2016.501.027 